\title{
Health Belief Model and Labelling Theory in the Analysis of Preventive Behaviors to Address Biopsychosocial Impacts of Sexual Violence among Street Children in Yogyakarta
}

\author{
Intan Noor Khalifah'), Argyo Demartoto'), Harsono Salimo3) \\ 1)Masters Program in Public Health, Sebelas Maret University \\ 2)Faculty of Social and Political Sciences, Sebelas Maret University \\ 3)Department of Pediatrics, Dr. Moewardi Hospital, Surakarta
}

\begin{abstract}
Background: Street children are at high risk of sexual violence. Necessary measures should be undertaken to address deleterious biopsychosocial impacts of sexual violence. This study aimed to analyze the preventive behaviors to address biopsychosocial impacts of sexual violence among street children in Yogyakarta using Health Belief Model and Labelling Theory.

Subjects and Method: This study was qualitative descriptive with phenomenology approach. The key informants for this study included Head of Rumah Impian Indonesia Foundation (a social non-government organization) and Director of PKBI, Yogyakarta. The main informants were the street children with assistance from Rumah Impian Indonesia Foundation. Supporting informants were health personnels of Jetis community health center and the street children's brothers.

Results: Street children who had experienced sexual violence were taken care by Rumah Impian Indonesia Foundation. The biopsychosocial effects of sexual violence included anxiety, anger, shock, trauma, fear, feelings of revenge, irritation, emotion, stress, unwillingness to eat, bad mood, and staying alone in the room. Preventive behaviour to overcome biopsychosocial impacts of sexual violence included forgetting, letting it go, not mentioning the problem again. Label or negative stigma given by the community to street children included marred children, dirty children, and social garbage.

Conclusion: Sexual violence experienced by street children cause various psychologic impacts, which calls for appropiate preventive behaviors to minimize the deleterious impacts of sexual violence. The social impacts of sexual violence in street children include labelling and negative stigma.
\end{abstract}

Keywords: Health Belief Model, Labelling Theory, sexual violence, biopsychosocial, preventive behavior, street children.

\section{Correspondence:}

Intan Noor Khalifah. Masters Program in Public Health, Sebelas Maret University, Jl. Ir. Sutami 36 A, Surakarta 57126, Central Java. Email: tanlifah@gmail.com Mobile: +6285728000164.

\section{BACKGROUND}

Cases of violence against children tend to be increasing, whether happening in the family, in school environment, and in society, the perpetrators are people who supposed to give protection to children (Bina Kesehatan Masyarakat dan UNICEF, 2007; Suradi, 2013; UNICEF, 2014; Sulistyaningsih and Faturochman, 2002). According to Unicef (2014) out of 190 countries show that there are about 6 out of 10 children have become the victims of physical, sexual, and psychological violence. And 1 of 10 girld or about 120 million girls all over the world have experienced sexual violence at the age of 20.

In Indonesia, cases of sexual violence against children have already lead to emergency condition, since wherever they are, they are overshadowed by the crime that may grasp their future. Children who live on the street and do not live with their 
parents are included as one of the groups who are susceptible to become victims of sexual violence. A lot of children who live on the street have experienced sexual violence and do not dare to make report to the authorities so that many cases are not revealed and the felony turns into silent crime (Noviana, 2015; Aswidah and Srimulyati, 2014; Erwin, 2013).

Sexual violence against street children can be in the form of sexual pre contact through words, touch, visual image or even with direct sexual contact involving street children. It is a common thing happens in the circles of street children, such as boy touching breast of the girl, and girl touching the boy's penis (Erwin, 2013).

A study conducted by Nada and Suliman (2010) about violence, harassment, alcohol and drugs abuse on 463 street children in Greater Cairo and 394 street children in Alexandria aged 15-17 year old found that there were about $53 \%$ or 36 female street children in Greater Kairo and 90\% or 30 female street children Alexandria have experienced sexual violence.

The data obtained from National Committee for Children Protection that at the present time there are 1.7 million of street children in 26 provinces who are susceptible to be victims of sexual violence. Whereas the result of a study conducted by Center for Study on HIV/ AIDS Atma Jaya in early 2016 on 43 street children in Jakarta who were susceptible aged 15-18 year found that 2 of 43 street children have experienced sexual violence and at the moment are pregnant out of wed lock as the result of sexual violence they endured. (CNN Indonesia, 2016; Pusat Penelitian HIV/ AIDS Unika Atma Jaya, 2016).

Sexual violence happen to children who live on the street becomes one of the serious violations to human rights and should be placed as extraordinary crime since it may generate prolonged impact for the rest of their life and may threaten the future of nation generation (Probo-siwi and Bahransyaf, 2015).

A study conducted by Sakalasastra and Herdiana in 2012 on children who live on the street stated that some children who experienced sexual violence would lost enthusiasm and feel powerless to live their life. They became more quite, fond of daydreaming, distress, and lack of sociallization with their environment.

The other impact faced by the victims of sexual violence is stigma or negative view from the society. Without guilt the society labels the children, victims of sexual violence as impure children, filthy, and disgraceful. The children who are victims of sexual violence are considered as a disgrace for the family, thus for hiding the disgrace eventually the child should be sent away for temporary so that the family would not be ashamed. A lot of children who become victims of sexual violence are discriminated and isolated by the family as well as the society in their surrounding (Bahri dan Fajriani, 2015; Lustanto, 2015).

The magnitude of the impacts generated by the sexual violence demands various parties to immediately perform preventive efforts or steps of sexual violence on children. In addition, it should be accompanied by curative efforts and steps as well as the treatment for children who have been the victims of sexual violence, so that they will not endure prolonged trauma and may restart their life in normal way.

Based on the description above the writer conducted analysis of Health Belief Model and Labelling Theory toward the behavior in coping biopsychosocial impacts as the result of sexual violence among street children of Yogyakarta City who were assisted in Rumah Impian Indonesia foundation Yogyakarta. 


\section{SUBJECTS AND METHOD}

The study was a descriptive qualitative study by using phenomenology study, to dig out the information about sexual violence happened to street children, the biopsychosocial impacts generated by sexual violence as well as the behavior of street children in overcoming the biopsychosocial impacts by means of Health Belief Model and labeling theory on street children who experienced sexual violence.

The study conducted in May to June 2017 in Yogyakarta City by considering there were street children in Yogyakarta City who had experienced sexual violence and there was Rumah Impian Indonesia Yogyakarta foundation that became an institution to assist and serve children who lived on the street.

The study used purposive sampling technique, in which the researcher selecting participants based on the possession of information. The key informant of the study was Head of Rumah Impian Indonesia Yogyakarta foundation and Director of PKBI Yogyakarta branch office, with the main informants were street children who were assisted of Rumah Impian Indonesia foundation and supporting informants that consisted of health workers of Puskesmas of Yogyakarta city and older sibling of one of the street children who experienced sexual violence.

Data collection techniques used were in-depth interview, observation and documentation study by using data collection instruments namely voice recorder, interview guidelines, observation guidelines, stationery, and laptop. The collected and obtained data were analyzed by using interactive model (Miles dan Huberman, 2007) that consisted of data reduction, data presentation, and conclusion making or data verification.

\begin{abstract}
RESULTS
From the result of in-depth interview with the informants, the researcher succeeded in identifying the cause of sexual violence on street children, the biopsychosocial impacts on street children who had experienced sexual violence, Health Belief Model toward the behavior in coping the biopsychosocial impacts on street children who experienced sexual violence, and the labeling given by society on street children who had experienced sexual violence.

In the study, all informants of street children who were interviewed by the researcher admitted that while they were working and living on the street, they experienced sexual violence in the form of sexual harassment which was perpetrated both by people they knew and they did not know. The incident had happened several years ago.
\end{abstract}

\section{The Cause of Sexual Violence against Street Children}

In this aspect, the researcher identified the informants' perceptions about things that became the cause of sexual violence against street children. One of the street children informants thought that sexual violence against street children happened because they did not have home, and there were senior street children who felt more dominant and the existence of mischievous female street children who might trigger men to conduct sexual violence. The following was the interview result conducted with the informant:

"What actually causes it? I think it is because street children do not have home, so they make us victims like that and also the usual factor that those who are bigger they have the power. And again my girl friends are mischievous so it arouses other people to do 
something sexual". (A1) Result of interview on 8 May 2017.

The same opinion is also conveyed by the main informant (A2) who stated that sexual violence against street children was caused by the existence of street children who wore revealing clothes, who could not be controlled and regulated that might invite or trigger men to conduct sexual violence:

"The cause actually comes from the person themselves. I mean, women with revealing clothes, it will invite men to do harassment. That is the first element. From the women themselves whose clothes cannot be controlled, cannot be regulated, it must happen that way. Since it really invite or attract men to do so". (A2) Result of interview on 09 May 2017.

\section{Biopsychosocial Impact on Street Children who Experienced Sexual Violence}

In this aspect, the researcher identified the impacts as the result of sexual violence, biologically, psychologically, as well as socially on street children who experienced sexual violence. In which all street children informants who experienced sexual violence endured psychological impacts. The following was a piece of the interview result conducted with the informant:

"Now, I feel worried, something like that. I'm shocked, angry, and upset also. I still remember it. So each time I walk alone and a motor pass by, I automatically cover myself. Like this, I just cover my breast. I'm afraid and it gives me shiver. What else? It was in my childhood, so until now I'm still in trauma with boys". (A1) Result of interview on 8 May 2017

The impacts of sexual violence on the main informant (A2) was the desire to take revenge, irritated, worried and afraid:
"The impact is more on the desire to take revenge, even though it does not give any physical effect. How it feels, seems it is still irritating. I just want to get over it, somehow I remember it once in a while, and then get irritated again. How can it happen to me? No man ever treated me that way before, and suddenly a stranger did that to me. I don't think I got traumatized but I feel over worried. I'm afraid it will happen again ". (A2) Result of interview on 9 May 2017

Furthermore, the impacts endured by the main informant (A3) was not far different from what was endured by main informants (A1 and A2). The following was a piece of the interview result conducted with the informant:

"I don't feel that way. I just got emotional and angry and irritated. If I just happen to meet that guy, I just keep silent, or glare at him. And if he sees me he will keep on going, and does not have guts to stop by. So, I'm just being normal. However, back then I was angry for quite sometime". (A3) Result of interview on 13 May 2017

\section{Behavior of Street Children in Coping the Biopsychosocial Impacts of Sexual Violence They Experienced}

In this aspect, the researcher identified the behaviour of street children in coping the biopsychosocial impacts generated by sexual violence they experienced. The following was a piece of the interview result with the informant:

"I play more often with my peers and ask for their advice. I take the positive from those advices. It helps me also, makes me less afraid. Since it was the first time for me. I don't get along with adults either. And if there is suspicious people I don't want to look at them, I 
don't look up if a stranger call me”. (A1)

Result of interview on 8 May 2017.

Behavior of main informant (A2) in coping the biopsychosocial impacts generated by sexual violence she experienced was by forgetting the incident, be more careful and more aware in wearing clothes:

"For me, I just forget about it, I mean I don't want tobring it up. That's it, what important is I should be more careful if I walk alone. Should be more aware in wearing clothes, to be not provocative anymore". (A2) Result of interview on 9 May 2017

While the behaviour of main informant (A3) was not far different from the previous opinion of main informant who stated that main informant (A3) had forgotten it, did not want to bring it up, and accept the incident of sexual violence she experienced. She made up and greeted the perpetrator. The following was a piece of the interview result with the informant:

"Well, I just ignored it. Simply by forgetting it, and not bringing it up. There no use of being angry all the time. It was not something far too much. Besides, it was something in the past. Let's just forget it. I accept it, I make up with him. Sometimes, when we came across, he said hello, and I responded". (A3) Result of interview on 13 May 2017

\section{Health Belief Model toward the behavior in Coping Biopsichosocial impacts on Street Children who Experienced Sexual Violence}

Health Belief Model in the study was used to identify health behaviour on the informants related to the behaviour in coping biopsychosocial impacts as the result of sexual violence they experienced. There were six components of Health Belief Model used in the study.

\section{a. Cues to Action}

In this aspect, the researcher identified the motivation of the informants to behave in coping biopsychosocial impacts as the result of sexual violence. The result of the study showed that all informants stated that the motivation to behave in coping biopsychosocial impacts as the result of sexual violence came from themselves. In addition they also obtained motivation from the people around them. There was a street child who obtained motivation from her husband, since only her and her husband who knew the incident:

"Yes, it was only my husband. He only said "Just be cool, but tell me if he did it again, I'll give him some lesson" I said "get over it, you don't need to, it's only small thing. I was afraid if it would be carried over, since they were emotional and involved in gangs. So, it would be better if only my husband and I who knew it . (A3) Result of interview on 13 May 2017

\section{b. Perceived Susceptibility}

In this aspect, the researcher identified the perception of street children on the level of susceptibility felt if they had conducted behaviour in coping the impact generated by sexual violence they experienced. All street children informants stated that they felt no susceptibility after they implemented the behaviour in coping the bipsychosocial impacts as the result of sexual violence experienced. There was street children informant who thought that if they did not implement the behaviour in coping biopsychosocial impacts then they would experienced more serious violence and impacts. The following was a piece of interview result with the informant:

"Well, It must happen again, maybe even worse if I don't take care of myself and don't get cautious. I myself who 
Journal of Maternal and Child Health (2017), 2(4): 309-323

https://doi.org/10.26911/thejmch.2017.02.04.03

will get the impacts and it can be more violent, I can get pregnant". (A1) Result of interview on 8 May 2017

\section{c. Perceived Severity}

On this aspect, the researcher identified street children perception on the severity they felt if they did not implement the behaviour in coping the bipsychosocial impacts as the result of sexual violence they experienced. The following was a piece of interview result with the informant:

"I think, if we can't get over it, it will be a certain trauma". (A1) Result of interview on 8 May 2017

While the main informant (A2) thought that if she did not forget the incident of sexual violence she experienced, then she would always remember and think about it. The following was a piece interview result with the informant:

"So far no. it's like, what is it? Now, I don't focus myself on it, don't really remember it, and don't think much about it. So, I don't remember anymore". (A2) Result of interview on 9 May 2017

Main informant (A3) thought that she was getting emotional if she did not forget the incident of sexual violence she experienced and could get angry as well as involved in an quarrel if she happened to meet the perpetrator of sexual violence:

"Well, if I don't get over it I'll get more eomotional. And if I meet him there will be a fight, an argument". (A3) Result of interview on 13 May 2017

\section{d. Perceived Benefit}

In this aspect, the researcher identified street children perception on the benefits felt after they implement the behaviour in coping biopsychosocial as the result of sexual violence they experienced. The following was a piece of interview result conducted with the informant:

"There is, it is worth it. So I can get over it and there is a benefit. I don't get traumatized. The trauma is gone, I don't remember it, and I don't feel afraid of boys anymore". (A1) Result of interview on 8 May 2017

It was also similar with the main informant (A2), that by forgetting the incident she was no longer overthinking and afraid anymore. The following was a piece of interview result conducted with the informant:

"I'm no longer overthinking it. I'm not worried what it is going to be. No fear anymore, it feels just normal". (A2) Result of interview on 9 May 2017

The benefits felt by the main informant (A3) was not far different from the main informants (A1 and A2) that after she implement the behaviour in coping biopsychosocial impacts generated by sexual violence, she was no longer overthinking the incident and she would take some lesson from that, to be more careful. The following was a piece of interview conducted with the informant:

"I take the lesson from it. Next time I won't sleep carelessly, be more careful and I'm not overthinking it anymore.". (A3) Result of interview on 13 May 2017.

\section{e. Perceived Barrier}

In this aspect, the researcher identified the perception of street children informant about the barriers they felt during implementing the behaviour in coping biopsychosocial impacts generated by sexual violence they experienced. All street children informants stated that they did not find any barrier when they implemented the behaviour. The main informant $\left(\mathrm{A}_{3}\right)$ stated that she did not faced any barrier when implemented the behaviour in coping 
the impacts generated by sexual violence because the people in her surrounding were unconcerned with others' business:

"Not really, people around here are ignorant. They are not concerned with other people's business". (A3) Result of interview on 13 May 2017

\section{f. Self Efficacy}

In this aspect, the researcher identified self efficacy of each street children informants to recover from biospychosocial impacts generated by sexual violence they experienced. The result of in-depth interview with all street children informants stated that all street children informants had faith that they could recover from the impacts after they implemented the behaviour in coping the impacts:

"Surely, I'm confident the trauma will gradually disappear. Yet, each time I meet him, I get angry again”. (A1) Result of interview on 8 May 2017.

"I have recovered, it means I'm no longer overthinking, if I pay attention to the way I dress. I'm pretty sure of it. Once I did feel wanted to give him a lesson, but now I don't feel it anymore. I just need to be more careful. No revenge and have forgotten it”. (A2) Result of interview on 9 May 2017.

"I managed to recover, I don't feel angry anymore. I have forgotten it". (A3) Result of interview on 13 May 2017.

The self efficacy of all street children informants was also supported by the opinion of the Head of PKBI Yogyakarta Branch Office:

"When the settlement, solution or anything given is in accordance with the problems, it will be in target, it will be more effective and they will recover.
The treatment is more effective“. (K2) Result of interview on 8 May 2017

\section{Labbeling Theory on Street Children who Experienced Sexual Violence}

In this aspect, the researcher identified the labelling theory on street children who had experienced sexual violence. All street children informants stated that they were labelled or given negative stigma by society when they were hovering the street:

"Yes there is, since we sleep in the street, people see us unpleasantly. They see us negatively". (A1) Result of interview on 8 May 2017

"Often they said we often steal, street children often steal and make affray. Once people judge us negatively, they will keep on judge us that way". A2) Result of interview on 9 May 2017.

All street children informants thought that anyone who had experienced sexual violence obtained negative stigma from the society, such as filthy and disgraceful children. It was supported by the opinion of the head of PKBI Yogyakarta Branch who stated that socially street children had obtained negative stigma from he society, and when they experienced sexual violence:

"Street children have undergone stigma and discrimination, socially they are considered as social problems bearer, lower class community, ragtag. Even without the case they have endured social impacts. And when the violence cases occurred to the marginalized group, there is some kind of neglect, what happen to them will be ignored”. (K2) Result of interview on 8 May 2017 


\section{DISCUSSION}

Street children is a term attached and usually given to children who spend some or the entire time in the street as well as in public places to conduct daily activitities. Living in the street, they should try and make a living to survive although they should adapt in order to be accepted by their surrounding. Demartoto (2012), conveyed that out in the street those children find freedom, pleasure and enjoy all available facilities as their wish. With the freedom they are able to conduct any activities they want to and may develop behaviours that are appropriate with the culture in the street.

According to UNICEF in 2012 it was predicted there were more than one billion children who lived and grew up out in the street. Their existence is generated by keep on going global population growth and urbanization. Purwoko (2013), stated that being street children is not a choice of life neither fun choice for them, the choice is generated by compulsion that they have to accept in the end. The causal factor can be in the form of poverty, domestic violence, and the absence of love from their family. It then later makes them behave unruly and break all the applied regulations.

Sexual violence refers to an action conducted by someone without consent in the form of sexual activity. While sexual violence on street children is in the form of sexual stimulus or sexual treatment either direct or indirectly that involves a street child. Sexual violence in the form of sexual harassment is a common problem among children who live in the street.

The informants' knowledge about the causes of sexual violence on street children may be categorized as quite good. Street children informants knew that sexual violence happened on street children may be generated by the unavailability of shelter, the occurrence of mischievous female street children and revealing clothes that may stimulate the perpetrators, the existence of senior street children who were dominant as well as people in the street who were very open and free. It is similar to Astri (2014) who stated children who live in the street are very susceptible and vulnerable to be sexual violence victims since they are in an place and environment which is unsupporting, tough, and dangerous with less monitoring from family and exposure to far ranging outside world. The patriarchy system also causes female street children to be more at risk or susceptible to experience sexual violence, in which men are more dominant than women (Reardon, 1996 and Medina, 2015).

Out in the street, those street children usually spend some or the entire time to make a living so that it cannot be deny they interact without restraint with many people with different nature and characters. Therefore they have a great possibility to meet and interact with sexual violence perpetrators. They have assembly points that are used by the perpetrators to conduct their sexual violence actions such as having sexual intercourse alternately with several people.

Sexual violence happens to street children may generate biological, physical, and social impacts. In the study the physical impacts are neither generated nor at issue, however all street children informants stated that sexual violence they experienced actually generated psychological trauma. The impacts of sexual violence experienced by the informants among others were the feeling of worried, shocked, anger, trauma, fear, disgust, the feeling to take revenge, upset, annoyed, loosing appetite, depressed, and stay quite in room. The study is similar with a study conducted by Celik and Media (2009) that 
in the study the majority of children who experienced sexual violence endured anxiety and anger.

Sexual violence is admitted as a form of persecution and serious violation toward human well beings, since sexual violence turns to enormous problem that may influence mental development of the victims at the present time as well as in the future (Vezina et al., 2013). WHO (2003) also stated that sexual violence may give negative impacts that significantly affects the health of victims who experienced it. Such as the potential of sexual or reproductive health problems, unwanted pregnancy, sexual transmitted diseases, HIV/ AIDS and increasing risky sexual behaviour. Moreover, sexual violence also may give impacts to mental health of the vivtims such as depression, addictive substance abuse, the intention to commit suicide. Sexual violence also becomes one of the causes of Post-Traumatic Stress Disorder (PTSD).

Behaviour is a response toward stimulus that underlies and causes the informants to take action. In which all street children informants stated that they implemented behaviour in coping the biopsychosocial impacts generated by sexual violence they experienced by forgetting and not bringing it up so that they may not remember the incident. In addition to forgetting there was a street child informant who asked for advice from someone older, and then hung out more often with their peers, they did not interact with more adult people and being more alert to people they just knew and suspicious.

It is in line with a study by McPherson et al (2012) which stated that behavioural therapy may decrease and prevent the duration of severity level and duration of acute psychological problem on the victims of sexual violence. Wilson (2006) also stated that the trauma healing effort conducted by the victims of sexual violence may not able to forget and erase the bitter experience they endured. Instead, the trauma healing effort only reduce the stress endured by the victims also may bring back the life control in order not to keep feeling guilty and ashamed.

Subsequently, what discussed in the study was Health Belief Model in coping the biopsychosocial impacts on street children who experienced sexual violence. Health Belief Model is a health behavior determinant model that is most used in academic world and health promotion. The concept of Health Belief Model explains that one's health behavior may get affected by individual belief and perception toward certain disease. (Rawlett, 2011).

The study discussed cues to action as one of the components of Health Belief Model Theory. Cues to action is one's impulse to be able to change his behaviour or habit. Cues to action is also clues for the individual to immediately take an action to implement health behaviours. In cues to action, the researcher identified the informants' motivation to behave in coping biopsycosocial impacts.

The foundation of street children informants to implement behaviour are the existence of informants' understanding on the impacts generated by sexual violence they experienced, also the occurrence of informants' expectation to recover from the biopsychosocial impacts generated by sexual violence. Street children informants stated that the motivation to implement behaviour came from they themselves, they also stated that they obtained encouragement and support from husband, and people in their surroundings. It is in accordance with the statement by Sulisyaningsih and Faturocham (2002) that stated in the healing process of the victims of sexual 
violence who endure trauma, the motivation may come from they themselves, in addition they also need encouragement and support from various parties. The support is required to encourage and help the victims to be able to accept the incident as life experience that must be accepted and endured.

The next component is perceived susceptibility felt by the street children informants after they implemented the behaviour in coping biopsychosocial impacts generated by sexual violence they experienced. Perceived susceptibility felt is one of the stronger perception to motivate someone in adopting health behaviour. The bigger risk they feel, the bigger possibility to be involved in the behaviour to reduce the risk.

All street children informants admitted that there was no susceptibility that they felt after they implemented the behavior in coping biopsychosocial impacts. They thought by forgetting and not bringing it up they would not remember the incident of sexual violence. However, they also admitted if they did not implement the behavior then the impacts might be worse.

The result of the study is in accordance with a study conducted by Musthaq et al (2015) which was conducted in Pakistan. The study stated that someone who had experienced sexual violence in the form of sexual harassment might endure depression 3-8 times than those who did not experience sexual violence. Sexual harassment may also lead to heavy stress onto the victims, make the victims feel sad, anxious, and depressed. Some studies also mentioned that crimal act in the form of sexual violence and sexual harassment happend during childhood despite having high risk in developing psychological disorder in the future, it also has high risk in turning the victim into the perpetrator in the future
(Ohlert et al, 2017; Ryan and Otonichar, 2016 and Maniglio, 2009).

Perceived severity is individual belief on disease severity or seriousness. The severity felt also refers to one's belief that he will go through difficulties as the result of the disease. Steet children informants admitted that if they did not implement the behavior in coping biopsychosocial impacts generated by sexual violence, then sexual violence they experienced would turninto a particular trauma for them and the emotion they felt would be getting bigger if they happened to come across the perpetrators. It is in line with what stated by Amado et al., (2015) that sexual violence criminal act may give serioud impact to the victims such as mental injuries and emotional suffering, major depression disorder, persistent depressive disorder, phobia and anxiety.

Perceived benefit is one's or individual perception or judgment toward the benefits after they implemented the behavior in reducing the risk of certain disease he suffer from. All street children informants stated that they felt the benefits after implementing the behavior in coping biopsychosocial impacts generated by sexual violence they experienced. The benefits they felt were in the form of the disappearance of trauma, forgetting and not bringing the incident up, the absence of fear, being more alert and they could take the lesson out of it.

Someone who thinks that the action or behavior he implemented may give a lot of benefit if he thinks that the conducted behavior may reduce the individual possibility to suffer from disease or severity of the impacts toward his life (Rosenstock and Becker, 1990). WHO (2003) stated that the effort or treatment on the victims of sexual violence may improve the quality of life and quality of support that is given to them. 
Barrier is a component of Health Belief Model which is the most significant in determining behaviour change, since behaviour change is something difficult for some people. The barrier refers to obstacle felt by an individual while he is changing and implementing the behaviour.

Based on the study result all main informants stated that there was no barrier they encountered during the implementtation of behavior in coping biopsychosocial impacts generated by sexual violence they experienced. It happened since anyone in their surroundings supported them to implement the behavior. According to the key informant, what became barrier was the society stigma that was attached on street children.

When the street children experience sexual violence, the society will judge as it is normally happen to those children. Gamble (2010) in a study about sexual violence against street children in Romania stated that limited access to social and healthcare service as well as numerous services that could not fulfil the specific needs of street children became the barrier for street children to conduct the coping effort toward biopsychosocial impacts. Therefore they found it difficult to conduct healing efforts toward the impacts of sexual violence.

Self efficacy refers to one's belief and confidence that comes from within about how confident they are in implementing health behavior. Based on the result of the study all informants admitted that they were confident to recover from biopsychosocial impacts if they had implemented the coping behavior toward biopsychosocial impacts generated by sexual violence. The occurrence of self efficacy to recover from the trauma generated by sexual violence is supported by the statement conveyed by the second key informant that when the settlement or solution was suitable with the problems and in target, then the treatment would be more effective and the victims of sexual violence might recover from the impact generated. Corrigan and Watson (2002) stated that self stigma is derived from the judgment toward oneself that impacts the behavior and motivation.

The researcher identified the labelling theory on street children who experienced sexual violence. According to Horwitz and Schied in 1999, labeling is a way to give label or nickname onto someone by giving description about the identity as a whole or by observing one behavior at a time. Labelling Theory is a theory of giving nickname or label toward someone or group of people with deviant behaviour, while they are interacting with the society. If it is continually conducted then the person will accept and be familiar with the nick name given.

All street children who became the informants of the study revealed that while they were out in the street they obtained negative label or stigma from the society, likewise, those who had experienced sexual violence. Negative stigma or label was given to them including filthy and disgraceful children. One of the informants in the study also stated that besides negative stigma, they also obtained unkind treatment from the society. And when the street children experienced sexual violence what they obtained from the society was only neglect.

As it is stated by Ogunkan and Adeboyeyo (2014) children who live in the street are susceptible to stigmatization given by the society through labelling or giving nick name. Moreover, street children are also vulnerable to discrimination therefore they are often neglected and feared by the society. 


\section{REFERENCE}

Amado BG, Arce R, Herraiz A (2015). Psychological Injury in Victims of Chils Sexual Abuse: A Meta-Analytic Review. Psychosocial Intervention. 24: 49-82.

Astri H (2014). Kehidupan anak Jalanan di Indonesia: faktor Penyebab, Tatanan Hidup dan Kerentana Berperilaku Menyimpang. Jurnal Aspirasi. 5(2) 146-155.

Aswidah R, Srimulyati E (2014). Darurat Kejahatan Seksual terhadap Anak. Jakarta: Komisi Nasional HAM.

Bahri S, Fajriani (2015). Suatu Kajian Awal terhadap Tingkat Pelecehan Seksual di Aceh. Jurnal Pencerahan. 9(1): 5065.

Bina Kesehatan Masyarakat, UNICEF (2007). Pedoman Rujukan Kasus Kekerasan terhadap Anak bagi Petugas Kesehatan. Jakarta: Direktur Bina Kesehatan Masyarakat dan UNICEF.

Celik SS, Media SB (2009). Verbal, Physical and Sexual Abuse among Children Working on the Street. Australian Journal of Advanced Nursing, 26(4): 14-22.

CNN Indonesia (2016) Anak Jalanan Rentan akan Kekerasan Seksual. http://www.cnnindonesia.com/nasio nal/20160516193039-20131111/anakjalanan-rentan-akan-kekerasanseksu al/. diakses tanggal 16 Januari 2017.

Corrigan PW, Watson AC (2002). The Paradox of Self Stigma and Mental Illness: Clinical Psychology: Science and Pratice.

Demartoto A (2012). Need Based Street Children Management in Surakarta Citu of Central Java Province of Indonesia. Asian Social Science. Vol 8(11): 107-118.
Erwin (2013). Karakteristik Anak Jalanan dan Bentuk-Bentuk Kekerasan terhadap Anak Jalanan di Kota Padang Provinsi Sumatra Barat. Antropologi Indonesia. 34(2): 176-188.

Gambel M (2010). Sexual Exploitation and Abuse of Street Children in Romania: Catalysts of Vulnerability and Challenges in Recovery. Lincoln: University of Nebraska.

Horwitz AV, Shield TL (1999). A Handbool for the Study of Mental Health: Social Contexts, Theories and Systems. Cambridge: Cambridge University Press.

Komisi Perlindungan Anak Indonesia (2016). Rincian Data Kasus Berdasarkan Klaster Perlindungan Anak 20112016. http://bankdata.kpai.go.id/tabulasi-data/data-kasus-per-tahun/rincian-data-kasus-berdasarka n-klasterperlindungan-anak-2011-201 6. diakses tanggal o5 Desember 2017.

Lustanto R (2015). Stigma Perempuan Korban Kekerasan Seksual dan Penghilangan Eksistensi. http:// www.jurnalperempuan.org/blog2/stigmaperempuan-korban-kekerasanseksual-dan-penghilangan-eksistensi.

Maniglio R (2009). The impact of child sexual abuse on health: A systematic review of reviews. Clinical Psychology Review. 29(7), 647-657.

McPherson, Scribano P, Steven J (2012). Barriers to Successful Treatment Completion in Child Sexual Abuse Survivors. Journal of Interpersonal Violence, 27(1):23-39.

Medina NA (2015). The Culture of Partiarchy and Its Effect on the Human Right of Girls-Children in Cagayan de Ora and Clevaria, Misamis. Philippine Institute for Development Studies. 44: 6. 
Miles MB, Huberman AM (2007). Analisis Data Kualitatif. Jakarta: UI Press.

Musthaq M, Safia S, Iqra I (2015) The Trauma of Sexual Harassment and its Mental Health Consequences Among Nurses. Journal of the College of Physicians and Surgeons Pakistan, 25(9): 675-679.

Nada K, Suliman E (2010). Violence, Abuse, Alcohol and Drug Use, and Sexual Behaviors in Street Children of Greater Cairo and Alexandria. Egypt. Wolters Kluwer Health. 24(2): S42.

Noviana I (2015). Kekerasan Seksual Terhadap Anak: Dampak dan Penanganannya. Jurnal Sosio Informa. 1(1): 13-28.

Ogunkan DV dan Adeboyejo AT (2014) Public Perception of Sreet Children in Ibadan, Nigeria. IFE Pyschologia. Vol 22 (1): 39-49.

Ohlert J, Corinna S, Thea R, Jorg F dan Marc A (2017). Comparison of Psychopathological Symptoms in Adolescent Who Experienced Sexual Violence as a Victim and/or as A Perpetrator. Journal of Child Sexual Abuse. 26 (4): 373-387.

Probosiwi R dan Bahransyaf D (2015). Pedofilia dan Kekerasan Seksual: Masalah dan Perlindungan terhadap Anak. Sosio Informa. Vol 01(1): 31-36.

Purwoko T (2013). Analisis Faktor-faktor penyebab Keberadaan Anak Jalanan di Kota Balikpapan. Jurnal Sosiologi. 1 (4): 13-25.

Pusat Penelitian HIV/AIDS Unika Atma Jaya Jakarta (2016). Anak Jalanan, Kelompok paling Rentan Alami Kekerasan Seksual. http://arc-atmaja .org/anak-jalanan-kelompok-palingrentan-alami-kekerasanseksual. diaks es tanggal 21 Januari 2017.

Rawlett K (2011). Analytical Evaluation of the Health Belief Model and the
Vulnerable Populations Conceptual Model Applied to a Medically Undeserved, Rural Population. International Journal of Applied Science and Technology; 1 (2): 15-21.

Reardon BA (1996). Sexism and the War System. New York: Syracuse University Press.

Rosenstock I, Becker HM (1990). The Health Belief Model and Personal Health Behavior. Charles B Slanck Inc: New Jersey.

Ryan EP, Otonichar JM (2016). Juvenile sex offenders. Current Psychiatry Reports, (18)67.

Sakalasastra P, Herdiana I (2012). Dampak Psikososial pada Anak Jalanan Korban Pelecehan Seksual yang Tinggal di Liponsos Anak Surabaya. Jurnal Psikologi Kepribadian dan Sosial. 1(02): 68-72.

Sulistyaningsih E, Faturochman (2002). Dampak Sosial Psikologis Perkosaan. Buletin Psikologi. 10(1): 9-23.

Suradi (2013). Problema dan Solusi Strategis Kekerasan terhadap Anak. Jurnal Informasi. 18(02): 183-199.

UNICEF (2012). The State of The World's Children 2012: Children in an Urban World. New York, NY; Author.

UNICEF (2014). New global data expose acute prevalence of violence against children: UNICEF. http;//www.unicef org/media/media75530.html.Diakses tanggal 13 Desember 2016.

UNICEF (2014). Ending Violance Againts Childre: Six Strategies for Action. New York: UNICEF.

Vezina DC, Daigneault I, Hebert M (2013). Lesoons Learned from Child Sexual Abuse Research: Prevalence, Outcomes and Preventive Strategies. Child and Adolesecent Psychiatry and Mental Health, 7(22): 2-9. 
Journal of Maternal and Child Health (2017), 2(4): 309-323

https://doi.org/10.26911/thejmch.2017.02.04.03

Wilson KA (2006). Sexual Assault and Posttraumatic Stress Disorder: A Review of The Biological, Psychological and Sociological Factors and Treatments. Journal of Medicine, 9 (2): 11-118.
World Health Organization (2003). Guidelines for Medico-legal Care for Victims of Sexual Violance. Geneva: World Health Organization. 